\title{
The Value of Investigations of the Incidence of Peptic Ulcer in the Families of Patients with Duodenal Ulcer
}

\author{
Z. KUBfČKOVÁ and K. T. VESELÝ
}

From the Institute of Haematology and Blood Transfusion and the Institute of Human Nutrition, Prague, Czechoslovakia

Many exogenous and endogenous factors are involved in the development of peptic ulcers. These factors are of individual importance for each subject and probably vary with time (Veselý, Kubícková, and Dvořáková, 1968). At present, great importance is ascribed to hereditary factors, though it is difficult to produce the necessary evidence (Bauer and Aschner, 1922; Fürst, 1936; Dubarry, Pisot, and Duhamel, 1960; Levrat, Lambert, and Bourrat, 1960; Levrat, Lambert, and Tissot, 1962; Jirásek, Gregor, and Černý, 1964 and 1965; Jirásek, 1967). Direct heredity is not assumed but rather a familial disposition conditioned by some genetically determined characteristics, either morphological, biochemical, or functional (Guiss and Stewart, 1948; Meyers, 1948; Tongen, 1950; Cox, 1952; Illingworth, 1956; Card and Marks, 1960; Shay and Sun, 1963; Landor, Portefield, and Wolff, 1966; Fodor et al, 1968).

Among the genetically determined characteristics investigated were blood groups of the ABO system (Clarke et al, 1959; Doll, Drane, and Newell, 1961; Kubičková and Veselý, 1966; Veselý et al, 1968), the secretor status of ABH blood group substances (Roberts, 1957; Levrat et al, 1960; Newman et al, 1961 ; Buckwalter, 1962; Kubičkova, 1964; Caldwell and Pigman, 1965; Langman and Doll, 1965; McConnell, 1966), and recently also the phenylthiocarbamide (PTC) test, ie, the ability to taste various concentrations of PTC (Kaplan et al, 1964; Kubičková, Dvořáková, and Veselý, 1968; Veselý et al, 1968). The relationship of the ABO blood groups to peptic ulceration has been investigated in the greatest detail. Based on many well-documented publications from various countries a proven relationship is considered to exist between duodenal ulcer and blood group $O$ (Melrose and Wallace, 1965; Veselý et al, 1968; Lambert and Martin, 1969).

Received 29 April 1971.
The familial incidence of peptic ulcer is known from many reports, which are however mostly only descriptive. The actual examination of relatives is difficult and therefore not much work has been done in this area (Bauer and Aschner, 1922; Doll and Kellock, 1951; Doll et al, 1961; Jirásek, 1967). The familial incidence of peptic ulcer and the ABO blood groups has, so far, only been investigated separately. We therefore decided to investigate them together, and in the first part of our work we assessed the incidence of peptic ulcer in the family history of duodenal ulcer patients, and the coefficient of relationship of the affected relatives. In the second part we were concerned with the familial incidence of ulcer in relation to the $\mathrm{ABO}$ blood group of the probands.

\section{Material and Methods}

The group of patients with duodenal ulcer who were investigated comprised 1026 subjects hospitalized in Prague institutes and clinics between 1955-68. In all patients the blood group of the $\mathrm{ABO}$ system was assessed. A family history using the genealogical method was obtained from 423 patients.

The genealogical method involves the elaboration of a complete pedigree, which, in addition to questions about the grand parents includes data on three generations: first generation-parents and their sibs; second generation-sibs of the proband and children of the parents' sibs (cousins of the proband); third generationchildren of the probands, children of the proband's sibs (nephews and nieces), and children of the proband's cousins. In the remaining 603 patients we were unable to obtain a complete pedigree as the probands did not know the fate of their relatives. A complete pedigree was drawn up for all 620 blood donors without peptic ulcer.

We used Kout's population group of 1142 subjects from Prague (Kout, 1959) to compare the frequency of ABO blood groups. Statistical evaluation of the significance was made by Woolf's method (1955). 


\section{Results}

Part 1. In addition to the proband one other member of the family was affected in $\mathbf{4 5 2}$ families (44.05\% of total group) of the 1026 patients with duodenal ulcer and their families who were investigated (Table I).

TABLE I

PERCENTAGE OF POSITIVE FAMILY HISTORIES IN DIFFERENT GROUPS

\begin{tabular}{l|c|c}
\hline \multicolumn{1}{c|}{ Group } & Number & $\begin{array}{c}\text { Positive } \\
\text { Family } \\
\text { History } \\
\left(\begin{array}{l}0 \\
\text { o. }\end{array}\right.\end{array}$ \\
\hline Controls & 620 & 13.55 \\
\hline Whole group & 1026 & 44.05 \\
Probands with complete pedigree & 423 & 52.48 \\
Probands with incomplete pedigree & 603 & 33.33 \\
\hline Case records of Veselý et al (1968) & 752 & 25.86 \\
\hline
\end{tabular}

In probands where a complete pedigree was obtained the percentage of positive family histories is even higher; even in probands with an incomplete pedigree the incidence is higher than in the data obtained from case sheets (Veselý et al, 1968). In the control group of 620 healthy subjects a positive family history was recorded in 84 families $(13.55 \%)$. Thus, relatives of patients with duodenal ulcer are affected three times more frequently than relatives of controls; we are aware of a possible error due to the fact that we did not take the size of the family into account.

We investigated the number of affected relatives according to the coefficient of relationship in those 423 patients with a complete pedigree. A coefficient of $\frac{1}{2}$ included the parents, sibs, and children of the proband; a coefficient of $\frac{1}{4}$ included the grandparents, the parents' sibs, and children of the proband's sibs; a coefficient of $\frac{1}{8}$ comprised cousins, ie, children of the parents' sibs, and a coefficient of $\frac{1}{16}$ their children.

Table II shows the affected relatives according to the coefficient of relationship in patients with duodenal ulcer compared with a control group. Relatives with the highest index are affected most. With the declining coefficient of relationship the incidence of relatives affected with peptic ulcers declines steeply. Data on relatives with a coefficient of $\frac{1}{8}$ and $-\frac{1}{16}$ may be biased by a certain error due to less information being available on more distant relatives, in particular among healthy probands who do not themselves suffer from peptic ulcer. The difference in the incidence of affected relatives with peptic ulceration in the control group and in
TABLE II

AFFECTED RELATIVES BY COEFFICIENT OF RELATIONSHIP

\begin{tabular}{|c|c|c|c|c|c|c|}
\hline \multirow{3}{*}{$\begin{array}{l}\text { Coefficient of } \\
\text { Relationship }\end{array}$} & \multicolumn{3}{|c|}{$\begin{array}{l}\text { Control Group } \\
\text { (620 subjects) }\end{array}$} & \multicolumn{3}{|c|}{$\begin{array}{l}\text { Duodenal Ulcer Group } \\
(423 \text { subjects })\end{array}$} \\
\hline & \multirow[t]{2}{*}{ No. } & \multicolumn{2}{|c|}{$\begin{array}{c}\text { Affected } \\
\text { Individuals }\end{array}$} & \multirow{2}{*}{ No. } & \multicolumn{2}{|c|}{$\begin{array}{c}\text { Affected } \\
\text { Parents }\end{array}$} \\
\hline & & No. & 0 & & No. & $\%$ \\
\hline $\begin{array}{l}\frac{1}{2} \\
\frac{1}{4} \\
\frac{1}{8} \\
\frac{1}{16} \\
\end{array}$ & $\begin{array}{l}3344 \\
7395 \\
5397 \\
4906\end{array}$ & $\begin{array}{r}57 \\
38 \\
12 \\
0\end{array}$ & $\begin{array}{l}1 \cdot 70 \\
0.51 \\
0 \cdot 22 \\
0\end{array}$ & $\begin{array}{l}2203 \\
5257 \\
3425 \\
3032\end{array}$ & $\begin{array}{r}210 \\
151 \\
47 \\
2\end{array}$ & $\begin{array}{l}9.53 \\
2.87 \\
1.37 \\
0.06\end{array}$ \\
\hline Total & 21,042 & 107 & 0.51 & 13,917 & 401 & 2.94 \\
\hline
\end{tabular}

patients with duodenal ulcer is highly significant $\left(\chi_{1}^{2}=30 \cdot 81\right)$.

When patients with duodenal ulcer were divided by sex, it was found that relatives of women were affected more frequently (Table III), the difference being highly significant $\left(\chi_{1}^{2}=15 \cdot 03\right)$.

\section{TABLE III}

NUMBER OF AFFECTED RELATIVES OF MALE AND FEMALE DUODENAL ULCER PATIENTS BY COEFFICIENT OF RELATIONSHIP

\begin{tabular}{|c|c|c|c|c|c|c|}
\hline \multirow{3}{*}{$\begin{array}{l}\text { Coefficient of } \\
\text { Relationship }\end{array}$} & \multicolumn{3}{|c|}{ Males (304 subjects) } & \multicolumn{3}{|c|}{ Females (119 subjects) } \\
\hline & \multirow[t]{2}{*}{ No. } & \multicolumn{2}{|c|}{$\begin{array}{c}\text { Affected } \\
\text { Individuals }\end{array}$} & \multirow{2}{*}{ No. } & \multicolumn{2}{|c|}{$\begin{array}{c}\text { Affected } \\
\text { Individuals }\end{array}$} \\
\hline & & No. & \% & & No. & $\%$ \\
\hline $\begin{array}{l}\frac{1}{2} \\
\frac{1}{4} \\
\frac{1}{8} \\
\frac{1}{16}\end{array}$ & $\begin{array}{l}1583 \\
3785 \\
2436 \\
2212\end{array}$ & $\begin{array}{r}135 \\
93 \\
29 \\
2\end{array}$ & $\begin{array}{l}8.53 \\
2.46 \\
1.19 \\
0.09\end{array}$ & $\begin{array}{r}620 \\
1472 \\
989 \\
820\end{array}$ & $\begin{array}{r}75 \\
58 \\
18 \\
0\end{array}$ & $\begin{array}{r}12.10 \\
3.94 \\
1.82 \\
0\end{array}$ \\
\hline Total & 10,016 & 259 & 2.59 & 3901 & 151 & $3 \cdot 89$ \\
\hline
\end{tabular}

Part 2. In this part of our work we devoted attention to the relationship between a family history of peptic ulcer and the proband's blood group. The group of 1026 patients was divided into two sub-groups: 574 subjects with a negative and 452 with a positive family history. The results are given in Table IV.

From Table IV it is apparent that, in keeping with data reported in the literature and our observations, the frequency of blood group $\mathrm{O}$ in patients with duodenal ulcer compared with the population as a whole is increased at the expense of blood group A. It is of interest that this abnormality is obviously caused by a high incidence of affected relatives among the group of patients with a positive family history, because in the group of patients with a negative family history the distribution of blood groups differs only slightly from that in controls.

An affected relative of a duodenal ulcer patient is 
TABLE IV

DISTRIBUTION OF BLOOD GROUPS IN PATIENTS WITH POSITIVE AND NEGATIVE FAMILY HISTORIES

\begin{tabular}{|c|c|c|c|c|c|c|c|c|}
\hline \multirow{4}{*}{$\begin{array}{l}\text { Blood } \\
\text { Group }\end{array}$} & \multicolumn{2}{|c|}{ Population } & \multicolumn{6}{|c|}{ Duodenal Ulcer Patients } \\
\hline & \multirow{3}{*}{ No. } & \multirow{3}{*}{$\%$} & \multicolumn{2}{|c|}{ Total } & \multicolumn{4}{|c|}{ Family History } \\
\hline & & & \multirow{2}{*}{ No. } & \multirow{2}{*}{$\%$} & \multicolumn{2}{|c|}{ Negative } & \multicolumn{2}{|c|}{ Positive } \\
\hline & & & & & No. & $\%$ & No. & $\%$ \\
\hline $\begin{array}{l}\mathbf{O} \\
\mathbf{A} \\
\mathbf{B} \\
\mathbf{A B}\end{array}$ & $\begin{array}{r}358 \\
516 \\
191 \\
77\end{array}$ & $\begin{array}{r}31.35 \\
45.18 \\
16.73 \\
6.74\end{array}$ & $\begin{array}{r}376 \\
411 \\
154 \\
85\end{array}$ & $\begin{array}{r}36.65 \\
40.06 \\
15.01 \\
8.28\end{array}$ & $\begin{array}{r}194 \\
240 \\
91 \\
49\end{array}$ & $\begin{array}{r}33.80 \\
41.81 \\
15.85 \\
8.54\end{array}$ & $\begin{array}{r}182 \\
171 \\
63 \\
36\end{array}$ & $\begin{array}{r}40.27 \\
37.83 \\
13.94 \\
7.96\end{array}$ \\
\hline Total & 1142 & $100 \cdot 0$ & 1026 & $100 \cdot 0$ & 574 & $100 \cdot 0$ & 452 & $100 \cdot 0$ \\
\hline
\end{tabular}

most likely to be a parent (44.69\%) (Table V). When the proband is blood group $\mathrm{O}$ the most frequently affected relative is a parent. A parent is less frequently affected if the proband has group A or B

\section{TABLE V}

INCIDENCE OF PEPTIC ULCERS IN PARENTS RELATED TO BLOOD GROUP OF PROBAND

\begin{tabular}{|c|c|c|c|c|c|c|}
\hline \multirow{3}{*}{$\begin{array}{l}\text { Blood } \\
\text { Group } \\
\text { of } \\
\text { Proband }\end{array}$} & \multirow{3}{*}{$\begin{array}{l}\text { No. of } \\
\text { Affected } \\
\text { Families }\end{array}$} & \multicolumn{2}{|c|}{$\begin{array}{c}\text { Families with } \\
\text { Affected } \\
\text { Parents }\end{array}$} & \multicolumn{3}{|c|}{ No. of Parents } \\
\hline & & \multirow{2}{*}{ No. } & \multirow{2}{*}{$\%$} & \multirow{2}{*}{ Total } & \multicolumn{2}{|c|}{ Affected } \\
\hline & & & & & No. & $\%$ \\
\hline $\begin{array}{l}\mathbf{O} \\
\mathbf{A} \\
\mathbf{B} \\
\mathbf{A B}\end{array}$ & $\begin{array}{r}182 \\
171 \\
63 \\
36\end{array}$ & $\begin{array}{r}89 \\
75 \\
29 \\
9\end{array}$ & $\begin{array}{l}48.90 \\
43.56 \\
46.02 \\
25.0\end{array}$ & $\begin{array}{r}364 \\
342 \\
126 \\
72\end{array}$ & $\begin{array}{r}90 \\
78 \\
30 \\
9\end{array}$ & $\begin{array}{l}24 \cdot 72 \\
22 \cdot 81 \\
23 \cdot 81 \\
12 \cdot 50\end{array}$ \\
\hline Total & 452 & 202 & 44.69 & 904 & 207 & 22.79 \\
\hline
\end{tabular}

(where the recessive allele $O$ may be present), and the parent is affected least frequently when the proband is blood group AB. The distribution is similar if the number of affected parents is expressed as a percentage; only half as many parents of probands with blood group $\mathrm{AB}$ are affected as are parents of probands with the other blood groups.

The statistical significance of the results is summarized in Table VI. The results of tests of group $\mathrm{O}$ as compared with the remaining groups are the most interesting. In the whole group of patients with duodenal ulcer and in the population the significance is at the $1 \%$ level. If we divide patients into those with a positive and those with a negative family history, the difference between patients with a negative history and the population is not significant, while the difference between patients with a positive history and the population is highly significant at the $0.1 \%$ level.

The results are remarkable when patients with a positive family history are tested against those with a negative family history; the significance being above the $5 \%$ level.

\section{TABLE VI}

SIGNIFICANCE ( $x^{2}$ TEST) OF FREOUENCY OF ABO BLOOD GROUPS IN PATIENTS WITH DUODENAL ULCER AND IN KOUT'S POPULATION (1959)

\begin{tabular}{|c|c|c|c|c|}
\hline \multirow[b]{2}{*}{ Blood Group } & \multirow{2}{*}{$\begin{array}{c}\text { Ulcer } \\
\text { Patients } \\
v \\
\text { Population }\end{array}$} & \multicolumn{2}{|c|}{ Population $v$. Patients } & \multirow{2}{*}{$\begin{array}{c}\text { Positive } \\
v \\
\text { Negative } \\
\text { Family } \\
\text { History }\end{array}$} \\
\hline & & $\begin{array}{l}\text { Negative } \\
\text { Family } \\
\text { History }\end{array}$ & $\begin{array}{l}\text { Positive } \\
\text { Family } \\
\text { History }\end{array}$ & \\
\hline $\begin{array}{l}O v A, B \text {, and } A B \\
A v O, B \text {, and } A B \\
B v O, A \text {, and } A B \\
A B v O, A \text {, and } B\end{array}$ & $\begin{array}{l}6.95 \\
5.92 \\
0.21 \\
1.86\end{array}$ & $\begin{array}{l}1.06 \\
1.82 \\
0.21 \\
1.79\end{array}$ & $\begin{array}{r}11 \cdot 65 \\
7 \cdot 73 \\
1.89 \\
0.72\end{array}$ & $\begin{array}{l}4.65 \\
1.69 \\
0.73 \\
0.18\end{array}$ \\
\hline
\end{tabular}

A significant difference was also found when comparing group A with the remaining groups of the entire sample of healthy subjects and patients (above the $2 \%$ level) and patients with a positive family history and the population (above the $1 \%$ level). The remaining results were not significant in any instance. The results in Table VI provide statistical evidence of the value of simultaneous assessment of the blood group and the occurrence of peptic ulcer in the family of patients with duodenal ulcer. In addition to blood group A, the family history is thus one of the most significant and constant characteristics of the disease.

\section{Discussion}

The familial aggregation of peptic ulcers has been investigated by many authors, though not in a uniform way and not equally thoroughly. The majority of authors described only the affected families and true genealogical analyses were made only in smaller series (Bauer and Aschner, 1922; Dubarry et al, 1960; Jirásek et al, 1964).

Figures of the percentage of cases with a positive family history of ulcer vary considerably and in selected groups are as high as $80 \%$ (Jirásek et al, 1965 ; Jirásek, 1967). In our unselected group of 423 patients with a complete pedigree the family history is positive in $52.48 \%$ of the cases, while in the control group of 620 subjects it is only positive in $13.55 \%$ cases.

Investigations of the degree of relationship of affected family members of probands revealed that the most frequently affected relatives are those with the highest coefficient of relationship. In relatives where all coefficients of relationship were investigated the number of affected relatives is almost 6 times greater than in the control group of healthy probands. 
In probands and their relatives the ratio of affected men and women is roughly $7: 3$. It was, however, revealed that relatives of women are affected significantly more frequently than relatives of men. As women suffer less frequently from duodenal ulcer (Veselý et al, 1968) this finding is compatible with the idea that a greater genetic disposition is needed for the manifestation of the disease in women; this disposition is then reflected by the fact that relatives are affected more frequently.

The problem of the relationship of disease and blood groups is discussed in many papers. We were able to confirm a predominance of blood group O in duodenal ulcer (Kubíčková and Veselý, 1966). This predominance is also seen when our present series is compared with Kout's population sample. This sample (Kout, 1959) was used because it is a representative one from the same locality and covers approximately the same period as our study; the size of the sample is also comparable with our group of patients and we consider it therefore more suitable than the smaller group of controls which was probably not representative.

In our group of duodenal ulcer patients the frequency of blood group $\mathrm{O}$ is also higher. A very interesting and quite a new finding is, however obtained when we divide the patients into those with and without a family history of peptic ulcer. In patients with a positive family history the incidence of group $\mathrm{O}$ is very high, while in patients with a negative family history it is close to the frequency in Kout's population.

Parents predominate among affected relatives with the highest coefficient of relationship, especially if the proband is blood group O. Parents of probands with blood group $\mathrm{AB}$ are relatively rarely affected. This is striking, as previously in our observations among patients with duodenal ulcer the incidence of group $\mathrm{AB}$ has always been raised (Kubíčová and Veselý, 1966; Veselý et al, 1968). In view of the small number of these probands and the low frequency of group $A B$ in the population, no final conclusions can be drawn. However, it is worth noting that the incidence of affected parents of patients with blood group $\mathrm{AB}$ (where allele $\mathrm{O}$ is lacking) is lower by almost half than the incidence of parents of patients with groups A and B (where there is a theoretical possibility that the recessive allele $A$ is present).

The families of our patients with a negative family history correspond to families with a 'solitary ulcer', while those with a positive family history correspond to 'ulcer families'-a term used by Jirásek (1967) to describe families where several members are affected. Our results reveal, however, that we may also use this term to describe families where, in addition to the proband, only one more member is affected; obviously we shall have to ascribe a greater importance to the coefficient of relationship than to the number of affected family members. Our observations also showed that peptic ulcer is not a uniform disease or at least that its genesis is not uniform and that several factors of varying importance participate in its development.

A positive family history of peptic ulcer is thus an important criterion and is one of the basic characteristics of a 'genuine' duodenal ulcer. Other factors include blood group $\mathrm{O}$, non-secretor status of $\mathrm{ABH}$ group substances, hyperacidity, early onset of the disease, severe course of the disease, and more frequent complications-appendicitis, smoking, etc (Veselý, 1966; Veselý et al, 1968). There is a real hope that detailed research directed in this way will provide further important findings, including a more accurate assessment of the bases of the heredity of ulcer disposition. So far, views on this problem are not uniform, but the most favoured opinion is of a recessive type of heredity. One cannot rule out the possibility that a dominant type of heredity with incomplete penetration may be a factor in at least some cases of 'genuine' duodenal ulcer. We shall be able to use this finding in clinical work to assess the diagnosis in obscure cases, to assess the prognosis, and to decide surgical treatment.

\section{Summary}

The incidence of peptic ulcer (regardless of the type of ulcer) in the family history ie, the number of affected families and the coefficient of relationship of the affected relatives in a group of 1026 patients with duodenal ulcer and in 620 controls was assessed. The relations between the incidence of ulcer in families of probands and blood groups of the ABO system was also studied.

In addition to the proband at least one other member of the family of patients with duodenal ulcer was affected in $44.05 \%$ of the families. In 423 families where a complete pedigree was obtained the percentage incidence was $52 \cdot 48 \%$. There was an affected member in only $13.55 \%$ of the control families.

The ratio of affected men and women among the probands and their relatives was about $7: 3$. The relatives of female patients were affected more frequently than relatives of male patients; a finding which was highly significant.

The affected relative of both the ulcer patients 
and the healthy subjects was most often a parent, sib, or offspring (with a coefficient of relationship of $\frac{1}{2}$ ). The percentage of affected relatives was approximately 6 times higher in patients than in healthy subjects.

In keeping with former observations the incidence of blood group $\mathrm{O}$ in the duodenal ulcer probands was higher than in a population sample. This increase was accounted for by the group of patients with a positive family history, as in patients with a negative family history the distribution of blood groups did not differ from that in the population.

The results indicate that a positive family history of peptic ulcer combined with blood group $\mathrm{O}$ is an important sign and significant characteristic of 'genuine' duodenal ulcer.

\section{REFERENCES}

Bauer, J. and Aschner, B. (1922). Konstitution und Vererbung bei Ulcus pepticum ventriculi und duodeni. Klinische Wochenschrift, $1,1250-1253$ and $1298-1302$.

Buckwalter, J. A. (1962). Peptic ulcer and the blood groups. Annals of the New York Academy of Sciences, 99, 81-88.

Caldwell, R. C. and Pigman, W. (1965). The carbohydrates of human maxillary glycoprotein in secretors and non-secretors of blood group substances. Biochemica et biophysica acta, 101, 157165.

Card, W. I. and Marks, I. N. (1960). The relationship between the acid output of the stomach following 'maximal' histamine stimulation and the parietal cell mass. Clinical Science, 19, 147163.

Clarke, C. A., Evans, D. A. P., McConnell, R. B., and Sheppard, P. M. (1959). Secretion of blood group antigens and peptic ulcer. British Medical fournal, 1, 603-607.

Cox, A. J., Jr. (1952). Stomach size and its relation to chronic peptic ulcer. Archives of Pathology, 54, 407-422.

Doll, R. and Kellock, T. D. (1951). The separate inheritance of gastric and duodenal ulcers. Annals of Eugenics, 16, 231-240.

Doll, R., Drane, H. and Newell, A. C. (1961). Secretion of blood group substances in duodenal, gastric and stomal ulcer, gastric carcinoma and diabetes mellitus. Gut, 2, 352-359.

Dubarry, J. J., Pisot, C., and Duhamel, J. (1960). Le facteur héréditaire dans la maladie ulcéreuse. Biologia medica, 49, 178-200.

Fodor, O., Vesta, S., Urcan, S., Popescu, S., Sulica, L., Jencica, R., Goia, A., and Ilea, V. (1968). Hydrochloric acid secretion capacity of the stomach as an inherited factor in the pathogenesis of duodenal ulcer. American fournal of Digestive Diseases, 13, 260265.

Fürst, A. (1936). Krodinnému ivýskytu vředu gastroduodenálního Časopis lékařu českých, 75, 508-516.

Guiss, L. W. and Stewart, F. W. (1948). Histologic basis for anacidity in gastric disease. Archives of Surgery, 57, 618-623.

Illingworth, C. F. W. (1956). Inborn and extraneous factors in the etiology of peptic ulcer. Fournal of Royal College of Surgeons Edinburgh, 2, 14-23.
Jirásek, V. (1967). Problémy Dědičnosti Peptického Vredu a Vředov@ Choroba Mladistvych. Dissertation, Faculty of Medicine Charles' University, Prague.

Jirásek, V., Gregor, O., and Černý, M. (1964). Některé genea= logické problémy vředové choroby. Československá gastroenterộ logie a výżiva, 18, 229-237.

Jirásek, V., Gregor, O., and Černý, M. (1965). Genealogicke problémy vředové choroby. Československá gastruenterologie vỹziva, 19, 54-56.

Kaplan, A. R., Fischer, R., Glanville, E., Powell, W., Kamionkow ski, M., and Fleshler, B. (1964). Differential taste sensitivities in duodenal and gastric ulcer patients. Gastroenterology, 47, 604 W)
609 .

Kout, $M$. (1959). Bestimmung der Blutgruppen $\mathrm{A}_{1} \mathrm{~A}_{2} \mathrm{BO}, \mathrm{MNS} \vec{\circ}$ $\mathrm{P}, \mathrm{Rh} / \mathrm{Hr}$, Kell und Duffy in der Prager Bevölkerung. Blut, $\mathbf{5}_{\mathbf{2}}$ 205-208.

Kubičková, Z. (1964). Vylučovatelství ABH substancí ve vztahul vředové chorobē. Bratislavské lekárske listy, 44, 423-428.

Kubičková, Z., Dvořáková, M., and Veselý, K. T. (1968). Endo genous factors in the inception of the ulcerous disease. Genetics in Clinical Medicine, Plzeñský lékařský sbornik, Suppl., 22, 175 177.

Kubičková, Z. and Veselý, K. T. (1966). Die Blutgruppen $A_{1} A_{2} B O \omega$ $\mathrm{Rh}_{0}(\mathrm{D})$, die Ausscheidungsfähigkeit der ABH-substanzen und die Ulcuskrankheit. Gastroenterologia, 105, 1-11.

Lambert, R. and Martin, F. (1969). Susceptibility to peptic ulcer and blood group substances. Digestion, 2, 298-303.

Landor, J. H., Porterfield, J. F., and Wolf, W. S. (1966). The parietal cell response to chronic gastric secretory stimulation. Surgery, Gynecology and Obstetrics with International Abstracts of Surgery, 122, 61-65.

Langman, M. J. S. and Doll, R. (1965). ABO blood group and $\overrightarrow{0}$ secretor status in relation to clinical characteristics of peptic ulcers $N$ N
Gut, 6, 270-273.

Levrat, M., Lambert, R., and Bourrat, C. (1960). La maladie ulcéreuse. Influence de l'hérédité et de l'environment. L'ulcèrê gastroduodínal des jumeaux. Presse médicale, 68, 431-434.

Levrat, M., Lambert, R., and Tissot, A. (1962). Hérédité de $\overline{\bar{O}}$ l'ulcère gastroduodénal et cas multiples familiaux. Fournal de@ genetique humaine, 11, 22-50.

McConnell, R. B. (1966). The Genetics of Gastro-intestinal Disorders, p. 282. Oxford University Press, London.

Melrose, A. G. and Wallace, J. (1965). Multiple cases of duodenalo ulcer in one family. Scottish Medical fournal, 10, 302-306.

Meyers, W. C. (1948). A study of gastric mucosa in various diseases affecting the upper part of the gastro-intestinal tract. Gastroenterology, 10, 923-938.

Newman, E., Naifeh, G. S., Auer, J. E., and Buckwalter, J. A. (1961). Secretion of ABH antigens in peptic ulceration and gastric carcinoma. British Medical fournal, 1, 92-94.

Roberts, J. A. F. (1957). Blood groups and susceptibility to disease. British Fournal of Preventive and Social Medicine, 11, 107-125.

Shay, H. and Sun, D. C. H. (1963). Etiology and pathology of gastric and duodenal ulcer. In Gastroenterology by H. L. Bockus. W. B. Saunders Company, London.

Tongen, L. A. (1950). The quantitative relationship between $O$ parietal cells and gastric acidity. Surgery, 28, 1009-1015.

Veselý, K. T. (1966). Peptický gastroduodenální vřed ve světle D novéjších poznatků. Dissertation, ÚVVL, pp. 255. Prague.

Veselý, K. T., Kubickková, Z., and Dvořáková, M. (1968). Clinical data and characteristics differentiating types of peptic ulcer. $\mathrm{N}$ Gut, 9, 57-68.

Woolf, B. (1955). On estimating the relation between blood group $\mathrm{N}$ and disease. Annals of Human Genetics, 19, 251-253. 